Portland State University

PDXScholar

\title{
Per-Person and Whole-Building VOC Emission Factors in an Occupied School with Gas-Phase Air Cleaning.
}

Brett W. Stinson

Portland State University, bstinson@pdx.edu

Aurélie Laguerre

Portland State University, aurelie.prot@pdx.edu

Elliott T. Gall

Portland State University, gall@pdx.edu

Follow this and additional works at: https://pdxscholar.library.pdx.edu/mengin_fac

Part of the Mechanical Engineering Commons

Let us know how access to this document benefits you.

\section{Citation Details}

Stinson, Brett W.; Laguerre, Aurélie; and Gall, Elliott T., "Per-Person and Whole-Building VOC Emission Factors in an Occupied School with Gas-Phase Air Cleaning." (2022). Mechanical and Materials Engineering Faculty Publications and Presentations. 387.

https://pdxscholar.library.pdx.edu/mengin_fac/387

This Post-Print is brought to you for free and open access. It has been accepted for inclusion in Mechanical and Materials Engineering Faculty Publications and Presentations by an authorized administrator of PDXScholar. Please contact us if we can make this document more accessible: pdxscholar@pdx.edu. 
Per-person and whole-building VOC emission factors in an occupied school with gas-phase air cleaning

\author{
Brett Stinson ${ }^{1}$, Aurélie Laguerre ${ }^{1}$, Elliott T. Gall ${ }^{1, *}$
}

${ }^{1}$ Portland State University, Department of Mechanical and Materials Engineering, $1930 \mathrm{SW} 4^{\text {th }}$ Ave, Portland, OR 97201, Suite 400, Portland, OR, USA.

\title{
*Corresponding author:
}

Department of Mechanical and Materials Engineering, 1930 SW $4^{\text {th }}$ Ave, Portland, OR 97201, Suite 400, Portland State University, Portland, OR, USA Email: gall@pdx.edu

\section{Abstract}

Using real-time measurements of $\mathrm{CO}_{2}$ and volatile organic compounds (VOCs) in the air handler of an occupied middle school, we quantified source strengths for 249 VOCs and apportioned the source to the building, occupants and their activities, outdoor air, or recirculation air. For VOCs quantified in this study, there is a source to the outdoors of $8.6 \pm 1.8 \mathrm{~g} / \mathrm{h}$ in building exhaust air, of which $5.9 \pm 1.7 \mathrm{~g} / \mathrm{h}$ can be attributed to indoor sources (the building and occupants and their activities). The corresponding whole-building area emission factor from indoor sources is $1020 \pm 300 \mu \mathrm{g} \mathrm{m}^{-2} \mathrm{~h}^{-1}$, including reactive VOCs like isoprene and monoterpenes $(33 \pm 5.1$ and $29 \pm 5.7 \mu \mathrm{g} \mathrm{m}^{-2} \mathrm{~h}^{-1}$, respectively). Per-person emission factors are calculated for compounds associated with occupants and their activities, e.g., monoterpenes are emitted at a rate $280 \pm 80 \mu \mathrm{g}$ person $^{-1} \mathrm{~h}^{-1}$. The air handler included carbon scrubbing, reducing supply air concentrations of 125 compounds by $38 \% \pm 19 \%$ (mean \pm std. dev.) with net removal of $2.4 \pm 0.4 \mathrm{~g} / \mathrm{h}$ of organic compounds from the building. This carbon scrubber reduces steady-state indoor concentrations of organics by $65 \mu \mathrm{g} / \mathrm{m}^{3}$ and the contribution of indoor sources of VOCs to the outdoor environment by $\sim 40 \%$. These data inform the design and operation of buildings to reduce human exposure to VOCs inside buildings. These data indicate potential for gas-phase air cleaning to improve both indoor air quality and reduce VOC emissions from buildings to the outdoor environment.

Synopsis: VOCs are emitted indoors and are exhausted outdoors; gas-phase air cleaning in buildings may ameliorate indoor and outdoor air quality impacts of VOC emissions

Keywords: PTR-MS, activated carbon, indoor source strength, indoor VOCs, urban air quality

37

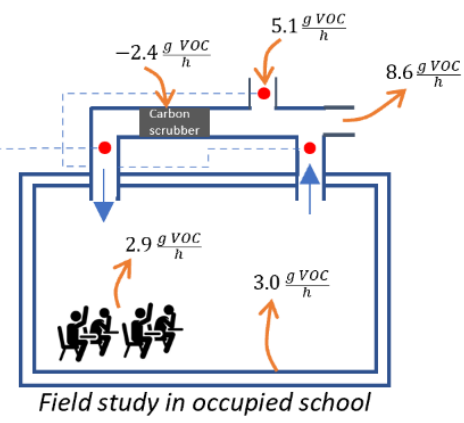




\section{Introduction}

Humans spend nearly $90 \%$ of their time indoors, ${ }^{1}$ where levels of volatile organic

41 compounds (VOCs) can accumulate to concentrations higher than outdoors. ${ }^{2,3}$ While indoor VOC

42 concentrations are routinely quantified, the strength (i.e., emission rate) of the myriad sources that

43 contribute to their accumulation is largely unquantified. ${ }^{4}$ VOCs and their chemical reaction

44 products degrade perceptions of indoor environmental quality, ${ }^{5-7}$ alter indoor chemistry, ${ }^{8-10}$ and

45 adversely impact respiratory health ${ }^{11-15}$ and cognition. ${ }^{16}$ Furthermore, emissions of VOCs indoors

46 are increasingly recognized for their impact on outdoor air quality. Human occupants and their

47 activities $^{4,17-20}$ and the use of volatile chemical products (VCPs) ${ }^{21-23}$ (e.g. personal care products,

48 solvents, adhesives, inks, etc.) emit VOCs indoors. Once exhausted outdoors, these compounds

49 participate in the production of outdoor air pollutants, like ozone and secondary organic aerosol

50 (SOA), ${ }^{24}$ and other species that may influence air quality at regional scales. For example, emissions

51 of fragranced personal care and cleaning products contribute meaningfully to urban ozone

52 production in New York $\mathrm{City}^{23}$ and VCPs can contribute to more SOA potential in cities than that

53 contributed by vehicles. ${ }^{25}$

54 The recent application of real-time chemical ionization mass spectrometers to indoor

55 environments has enabled the identification and quantification of VOC emission rates on a per-

56 person basis. Tang et al. ${ }^{17}$ quantified VOCs in a university classroom setting with between 26 to

5767 college-aged students present. This study found that occupants and their activities were

58 responsible for $57 \%$ of emissions, and that compounds associated with personal care products

59 and human metabolism were the dominant sources. Stönner et al. ${ }^{18}$ quantified per-person VOC

60 emission rates in a German cinema occupied by 50-230 people; the study was arranged to

61 distinguish between compounds emitted by adults and children. Pagonis et al. ${ }^{19}$ measured VOCs 
62 inside of a university art museum that nearly 300 people cycled through in the course of an

63 evening. Across studies, emission rates of some compounds associated with human metabolism

64 and activity (e.g., isoprene and monoterpenes) were in reasonable agreement; emission rates of

65 other compounds were more variable, e.g., ethanol and acetaldehyde. These results imply the

66 need for more studies of diverse populations and buildings to better characterize indoor VOC

67 source strengths.

68 Indoor environments contain diverse sources of VOCs. With temporally and spatially

69 resolved VOC measurements, source strengths can be separated into contributions from outdoor

70 air, supply air, building materials, etc. using mass balance principles. For instance, Tang et al. ${ }^{17}$

71 found that $57 \%$ of VOC emissions originated from occupants, $35 \%$ from supply air and $8 \%$ from

72 indoor, non-occupant sources. In contrast, Lunderberg et al. ${ }^{4}$ quantified and apportioned more

73 than 200 VOCs in two California homes over multiple seasons, finding that continuous indoor

74 sources from buildings and building materials were the largest contributor to exposure, though

75 occupant-related activities proved to also be a significant source. At the university art museum

76 where Pagonis et al. ${ }^{19}$ took place, surface deposition and ventilation were the dominant VOC

77 sinks in the building.

In all buildings, indoor air is exchanged for outdoor air via ventilation and/or infiltration.

79

80

81

82

83

84

These processes exhaust indoor VOCs and products of indoor VOC chemistry to the outdoors while simultaneously introducing VOCs of outdoor origin to the indoor space. Outdoor air ventilation is of concern if a building is in proximity to sources of air pollution, like roadways..$^{26,27}$ Many buildings are located near major roadways: $40 \%$ of urban populations and $15 \%$ of schools are located near a major highway or road. ${ }^{28,29}$ Concentrations of traffic-related air pollution (TRAP) VOCs are elevated within a zone of 500-2000 meters downwind of a major roadway..$^{30,31}$ 
Exposure to TRAP has been proven to be a source of health-related issues for humansparticularly for vulnerable populations, such as children. ${ }^{32}$

Air cleaning systems are an option to improve ventilation air quality. Air handlers typically include particle filters but systems targeting gas-phase compounds are rarely present. Prior studies investigating gas-phase air cleaning in schools have focused on portable systems. Estimates of activated carbon air cleaning effectiveness show mixed results for reducing concentrations of

91 VOCs in school indoor air, ${ }^{33-35}$ often noted to result from variability in the indoor source strength

92 across periods of air cleaner state (i.e., on and off). To our knowledge, there exist no 93 comprehensive in-situ assessments of whole-building activated carbon air cleaning performance. built in close proximity to Interstate-5, a heavily trafficked highway in Portland, Oregon, USA. ${ }^{36}$ The building was renovated in 2018, including the addition of high-efficiency particle filters and an activated carbon gas-phase air scrubber to the building air handling system. An air monitoring campaign evaluated outdoor and indoor air quality at the school site over three deployment phases, each lasting for six weeks. ${ }^{37}$ This study focuses on the final field campaign, which included hightime resolution measurements of organic compounds via proton transfer reaction - time of flight - mass spectrometry (PTR-ToF-MS) and other air pollutants at multiple locations in the HTMS

102 air handling system. With these data, we quantify airflows, VOC source strengths, and single-pass

103 removal efficiencies of VOCs through the carbon scrubber for the occupied middle school. This 104 study fills a gap in quantifying sources and sinks of VOCs in K-12 institutions, environments 105 important to children's health. ${ }^{38,39}$

\subsection{Site description}


109 Portland, Oregon, USA and in 2019 had an enrollment of 472 students with 33 faculty

110 members. $^{40}$ The renovated air handling system that serves the entire school is shown in Fig. 1,

111 along with a schematic showing sampling locations in the air handler. The renovated air handling

112 system includes MERV8 particle filters (Camfil Farr 30 x 30, 2”) followed by MERV16 high-

113 efficiency particle filters (Camfil, Durafil ES ${ }^{2}$, V-bank). A functionalized activated carbon

114 scrubber (Camfil, LGX048) is present downstream the MERV16 filter bank. The air handler is

115 active each Monday through Friday, 06:00 to 18:00 local time, during which the system

116 circulates, conditions, and cleans a mixture of return and outdoor air that is sent to the building

117 as supply air. The building air temperature was stable across the study period (May 27 $7^{\text {th }}, 2019$

118 the unoccupied day, and three subsequent days when the building was occupied) averaging 23

$119{ }^{\circ} \mathrm{C} \pm 0.7{ }^{\circ} \mathrm{C}$ during the timeframe of 09:00-18:00.
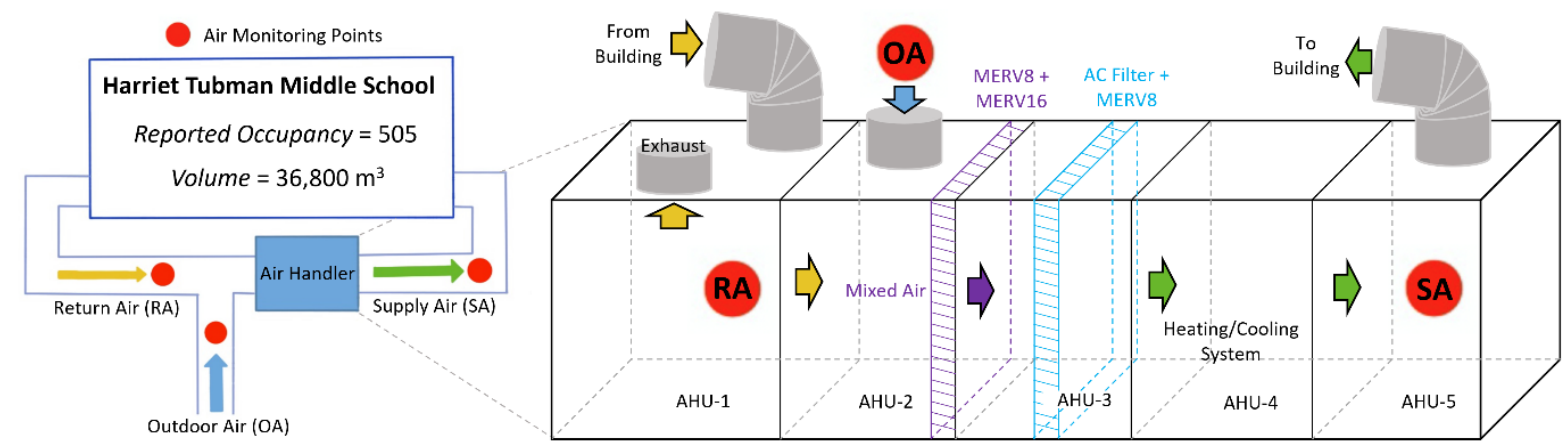

121 Figure 1. Schematic of Harriet Tubman Middle School and the renovated air handler installed in 122 Summer 2018. The volume of the building is $36,800 \mathrm{~m}^{3}$ and the reported occupancy for 2019 123 was 505. The air-cleaning system was outfitted with MERV 8, MERV 16, and activated carbon 124 filters. Volatile organic compound concentrations were monitored at return air, outdoor air, and 125 supply air monitoring points. $\mathrm{RA}=$ return air, $\mathrm{OA}=$ outdoor air, $\mathrm{SA}=$ supply air. $\mathrm{MERV}=$ 126 minimum efficiency reporting value, a standard metric for reporting particle removal efficiency 127 of mechanical filters. AHU = air handling unit.

\subsection{Instrumentation and Calibration}

VOC sampling was conducted using a proton transfer reaction - time of flight - mass 
spectrometer (PTR-ToF-MS, Ionicon, PTR-1000) measuring across 17-280 amu for compounds with a proton affinity higher than that of $\mathrm{H}_{2} \mathrm{O}$ (i.e. most VOCs). ${ }^{41}$ The operating conditions were: $\mathrm{T}_{\text {drift }}=60^{\circ} \mathrm{C}, \mathrm{P}_{\text {drift }}=2.2 \mathrm{mbar}, \mathrm{U}_{\text {drift }}=600 \mathrm{~V}$, which resulted in electric field strength to number

134 density ratio $\mathrm{E} / \mathrm{N}=135 \mathrm{Td}$ (Townsend, $1 \mathrm{Td}=10^{-17} \mathrm{~V} \mathrm{~cm}^{2}$ ). VOC concentrations were sampled 135 in three locations in the AHU by use of a switching valve, which alternated between return aeq.ir, outdoor air, and supply air in regular, ten-minute intervals (see Fig. 1). For identification and 137 quantification details and a list of select compounds that were putatively identified, see further description and Table S1 in the Supporting Information. Additionally, two sensors (Onset MX1102) were used to measure temperature, relative humidity, and $\mathrm{CO}_{2}$ concentrations in return and supply air. $\mathrm{CO}_{2}$ sensors were calibrated prior to deployment, however, we observed sensor

141 drift over the course of the campaign. We developed a correction for the $\mathrm{CO}_{2}$ monitors from a 142 regression of the supply air vs. return air measured $\mathrm{CO}_{2}$ concentrations for the period from 02:00143 04:00, when the air handler was idle and the building was post-occupancy for greater than six 144 hours. Further details concerning the instrumentation, sampling method, and analysis of data 145 collected during the field campaign can be found in Laguerre et al. $2020 .{ }^{37}$

\section{$146 \quad 3.3$ Data analysis}

\section{$147 \quad 3.3 .1 \quad$ Source strength analysis}

148 The mass balance shown in eq. 1, similar to Tang et al., ${ }^{17}$ enables calculation of the mass of 149 a VOC emitted into the building:

$$
M=\lambda_{S A} V \int_{t_{0}}^{t_{1}}\left(C_{i, R A}-C_{i . S A}\right) d t+V \int_{t_{0}}^{t_{1}} d C_{R A}
$$

150 where $M$ is the total mass of a compound emitted into the school $(\mu \mathrm{g}), \lambda_{S A}$ is the supply air

151 change rate $\left(\mathrm{h}^{-1}\right), V$ is the school's volume $\left(\mathrm{m}^{3}\right), t_{0}$ and $t_{1}$ are the beginning and end, respectively, 
152 of a period of analysis on a given day (h), and $C_{i, R A}$ and $C_{i, S A}$ are the concentration of a VOC

$153\left(\mu \mathrm{g} / \mathrm{m}^{3}\right)$ measured at the return and supply air monitoring points, respectively.

154 While time-varying VOC concentrations were measured with PTR-ToF-MS, lack of

155 access to the ducting prohibited direct measurement of time-varying airflow. Additionally, while

156 annual enrollment data is available, occupancy $(N)$ is variable day-to-day. In the Supporting

157 Information (including the schematic shown in Fig. S1), we describe our method to determine

158 the outdoor air change rate $\left(\lambda_{O A}\right),{ }^{42}$ supply air change rate $\left(\lambda_{S A}\right)$, and the number of occupants

159 present in the building $(N)$ across each day.

160 VOC source strengths were calculated similar to a prior study ${ }^{17}$ and were apportioned

161 into four categories. The school was unoccupied on Monday, May 27th due to the Memorial Day

162 holiday while the air handler operated on its normal weekday schedule (operational from 06:00 -

163 18:00, local time). We first calculated the mass emitted (eq. 1) of each VOC in the absence of

164 occupants on May $27^{\text {th }}$ over an analysis period of $\sim 10: 00-12: 00$. This timeframe was selected

165 as it encompassed the same timeframe of analysis of subsequent occupied days. Source strengths

166 calculated during the unoccupied day are categorized as emissions from the building $\left(S_{\text {Building, }}\right.$

$167 \mu \mathrm{g} / \mathrm{h})$, shown in eq. 2 :

$$
S_{\text {Building }}=\left(\frac{M}{t_{1}-t_{0}}\right)_{\text {vacant day }}
$$

168 where all terms are as described previously.

169 The source strength attributable to occupants and their activities, $S_{\text {Occupants }}(\mu \mathrm{g} / \mathrm{h})$ is

170 calculated as shown in eq. $\mathbf{3}$ :

$$
S_{\text {Occupants }}=\left(\frac{M}{t_{1}-t_{0}}\right)_{\text {occupied day }}-\left(\frac{M}{t_{1}-t_{0}}\right)_{\text {vacant day }}
$$


171 where all terms are as described previously, $t_{1}$ and $t_{0}$ on occupied days are the end and beginning

172 of a period of stable occupancy, respectively, which occurred within the 10:00- 12:00 timeframe

173 and is determined as described in the Supporting Information.

174 Whole-building emission factors are determined by normalizing the sum of $S_{\text {Building }}$ and

175 SOccupants by the building footprint $\left(\mathrm{m}^{2}\right)$ and per-person emission factors are determined by

176 normalizing $S_{\text {Occupants }}$ by the occupancy (persons). For these calculations the average of $S_{\text {Occupants }}$

177 over the three occupied days was used.

178 Supply air acts as a source of VOCs to the building, with contributions from outdoor air

179 and recirculation air. The indoor source strength from supply air recirculated from the building

180 after passing through the activated carbon scrubber $\left(S_{\text {supply, recirc }}, \mu \mathrm{g} / \mathrm{h}\right)$ is shown in eq. 4 :

$$
S_{\text {supply,recirc }}=\left[\left(\lambda_{S A}-\lambda_{O A}\right) C_{i, R A} V\right] \times\left(1-\eta_{i}\right)
$$

181 where $S_{\text {supply,recirc }}$ is the source strength in recirculation air $(\mu \mathrm{g} / \mathrm{h}), \lambda_{O A}$ is the outdoor air change

182 rate $\left(\mathrm{h}^{-1}\right), \eta_{i}$ is the removal efficiency across the air handler $(-)$ and other terms are as defined

183 previously.

184 The indoor source strength of supply air from outdoor air after passing through the

185 activated carbon scrubber $\left(S_{\text {supply,outdoor, }} \mu \mathrm{g} / \mathrm{h}\right)$ is shown in eq. 5:

$$
S_{\text {supply,outdoor }}=\left[\lambda_{O A} C_{i, O A} V\right] \times\left(1-\eta_{i}\right)
$$

186 where $C_{i, O A}$ is the concentration of a VOC in outdoor air $\left(\mu \mathrm{g} / \mathrm{m}^{3}\right)$, time-averaged over the period

187 of analysis, and other terms are as defined previously.

$188 \quad$ 3.3.2 Air handler removal efficiency and sink strength

Removal efficiency across the air handling system that included activated carbon scrubbing

190 is calculated using a time-averaged mass balance on the air handler as shown in eq. 6 : 


$$
\eta_{i}=1-\frac{\lambda_{S A} C_{i, S A}}{\lambda_{S A} C_{i, R A}-\lambda_{O A} C_{i, R A}+\lambda_{O A} C_{i, O A}}
$$

191 where all terms are as defined previously.

$$
\text { The sink strength across the air handler, } S_{\text {air handler }}(\mu \mathrm{g} / \mathrm{h}) \text {, is determined from eq. } 7 \text { : }
$$

$$
S_{\text {air handler }}=\left[\left(\lambda_{S A}-\lambda_{O A}\right) C_{i, R A} V\right] \times\left(\eta_{i}\right)+\left[\lambda_{O A} C_{i, O A} V\right] \times\left(\eta_{i}\right)
$$

193 where all terms are as described previously.

194 Note that in eq. 7, a positive value of $S_{\text {air handler }}$ indicates removal of the compound

195 across the air handler. A full description of the assumptions used to calculate removal efficiency 196 can be found in the Supporting Information, including a schematic of the air handler in Fig. S2.

\subsubsection{Whole-building emissions to the outdoors}

199 shown in eq. 8:

$$
S_{\text {exhaust }}=\lambda_{E A} C_{i, E A} V
$$

where $\lambda_{E A}$ is the exhaust air change rate $\left(\mathrm{h}^{-1}\right)$, assumed to equal the outdoor air change rate $\lambda_{O A}$, 201 since the building is designed for balanced ventilation, $C_{i, E A}$ is the compound's exhaust air 202 concentration $\left(\mu \mathrm{g} / \mathrm{m}^{3}\right)$ which is assumed to equal $C_{i, R A}$ since return air is immediately exhausted 203 after entering the air handler (see Fig. 1), and other terms are as described previously.

The VOC source strength from building exhaust to the outdoors can also be determined 205 by summing the relevant sources to the building, as shown in eq. 9:

$$
S_{\text {exhaust }}=\lambda_{O A} C_{i, O A} V+S_{\text {building }}+S_{\text {occupants }}-S_{\text {air handler }}
$$
where all terms are as described previously.

The contribution of indoor processes to VOC source strength in building exhaust to the outdoors ( $S_{\text {ehxaust,indoor }}, \mu \mathrm{g} / \mathrm{h}$ ) is defined in eq. 10: 


$$
S_{\text {exhaust,indoor }}=S_{\text {exhaust }}-\lambda_{O A} C_{i, O A} V=S_{\text {building }}+S_{\text {occupants }}-S_{\text {air handler }}
$$

where all terms are as described previously.

210 The derivation leading to eqs. $\mathbf{9}$ and $\mathbf{1 0}$ is shown in the Supporting Information, including

211 Fig. S3, which shows a schematic of building airflows. Note that we assess the role of removal

212 across the air handler by comparing the result of eqs. $\mathbf{9}$ and $\mathbf{1 0}$ with and without the contribution

213 of the carbon scrubber (i.e., the latter where $S_{\text {air handler }}=0$ ).

214 3.3.4 Uncertainty analysis

215 Uncertainties in reported parameters are either the greater of variability across parameter

216 estimates made during each occupied day (evaluated as the standard deviation across three days)

217 or the propagated error. Error propagation was conducted using the relevant equation for source

218 strength or removal efficiency. Error in each parameter used in uncertainty analysis is

219 summarized in Table S2 of the Supporting Information. Note that in the case of $S_{\text {Building, only }}$

220 propagated error is reported since there were not multiple estimates made for this parameter.

\section{4. Results and Discussion}

\section{$222 \quad 4.1$ Occupant density and airflows}

Results of calculations to determine the occupancy $(N)$, outdoor air change rate $\left(\lambda_{O A}\right)$, and

224 supply air change rate $\left(\lambda_{S A}\right)$ are shown in Table 1. The school district estimated the total number

225 of students and faculty to be $505,{ }^{40}$ which is in close alignment with the average calculated

226 occupancy of 513. A validation of flowrate estimates made here is that the facilities engineer

227 reported a design supply air flowrate of $68,000-100,000 \mathrm{~m}^{3} / \mathrm{h}$, in the lower range during spring

228 due to mild outdoor temperatures. Our calculated average supply air flowrate $\left(\lambda_{S A} \times V\right)$ is 66,000

$229 \mathrm{~m}^{3} / \mathrm{h}$. This value is in general agreement with the facility engineer's explanation of the system

230 operation. 
231 Table 1: Summary of occupancy and air change rates calculated for the studied middle school.

\begin{tabular}{|c|c|c|c|c|c|c|c|}
\hline & \multicolumn{2}{|c|}{ Occupancy } & \multicolumn{2}{|c|}{ Outdoor air change rate } & \multicolumn{2}{c|}{ Supply air change rate } \\
\hline Date & $N$ & $\mathrm{~S}_{\mathrm{N}}{ }^{*}$ & $\lambda_{\mathrm{OA}}\left(\mathrm{h}^{-1}\right)$ & $\mathrm{SE}^{\#}$ & $r^{2}$ & $\lambda_{\mathrm{SA}}\left(\mathrm{h}^{-1}\right)$ & $\mathrm{S}_{\lambda \_\mathrm{SA}}\left(\mathrm{h}^{-1}\right)^{\&}$ \\
\hline $5 / 28 / 19$ & 448 & 87 & 0.85 & 0.023 & 0.94 & 2.0 & 0.21 \\
\hline $5 / 29 / 19$ & 540 & 98 & 0.87 & 0.032 & 0.93 & 1.7 & 0.23 \\
\hline $5 / 31 / 19$ & 552 & 120 & 1.15 & 0.035 & 0.94 & 1.7 & 0.24 \\
\hline Average & 513 & 100 & 0.96 & 0.030 & 0.94 & 1.8 & 0.23 \\
\hline
\end{tabular}

232

233

234

235

236

237

238

239

240

241

242

243

244

245

246

247

248

249

250

251

252

* estimated uncertainty from error propagated through equation S1 of the Supporting Information

${ }^{\#}$ standard error (SE) of the slope of the linear regression to determine outdoor air change rate

\&estimated error in supply air change rate from sensitivity analysis on equation S2 of Supporting Information; value reported is the estimated standard deviation.

The semi-validation of occupancy and airflow calculations through independent

parameter estimates demonstrates that our approach is reasonable. However, this method may not be widely applicable to other building types, as it relies on occupancy trends that include discrete step-changes from no occupancy to full occupancy (and vice versa) and a period of stable occupancy. Uncertainties in determined outdoor and supply air change rates are likely higher than those that would result from direct measurements.

\subsection{Source apportionment}

Shown in Fig. 2 are the results of the source apportionment of indoor VOC source strengths across the 249 compounds quantified in this analysis; the twenty compounds with the highest total indoor source strength are detailed in the inset. Our estimates of source strength include the impact of indoor VOC transformation and partitioning that may alter indoor concentrations as air moves through the building to the return air monitoring point in the air handler. Thus, subsequent area and per-person emission factor calculations based on these source strengths also include these effects.

We observe total source strengths that range over more than three orders of magnitude, from $-0.02 \mathrm{mg} / \mathrm{h}$ to $1800 \mathrm{mg} / \mathrm{h}$. The distribution $\left(10^{\text {th }}\right.$ percentile $=3.6 \mathrm{mg} / \mathrm{h}$, median $=13 \mathrm{mg} / \mathrm{h}$, $90^{\text {th }}$ percentile $\left.=120 \mathrm{mg} / \mathrm{h}\right)$ of total indoor source strength shows high skew $($ skewness $=5.8)$; 
many compounds have small source (or sink) strength relative to the compounds shown in the

254 inset of Fig. 2. Source and sink strengths enable indoor exposure modeling and the

255 apportionment enables identification of opportunities for intervention. For example, compounds

256 with high contributions from outdoor air (e.g., m108_1, shown in the inset) would not be

257 effectively addressed through increased outdoor air exchange. Conversely, m59 (putatively

258 identified as acetone), with high relative contributions from indoor sources, will have substantial

259 reductions in indoor concentration with increased outdoor air exchange. As will be discussed in

260 Sections 4.3 and 4.4, these data also enable estimation of whole-building area emission factors

261 and per-person emission factors.

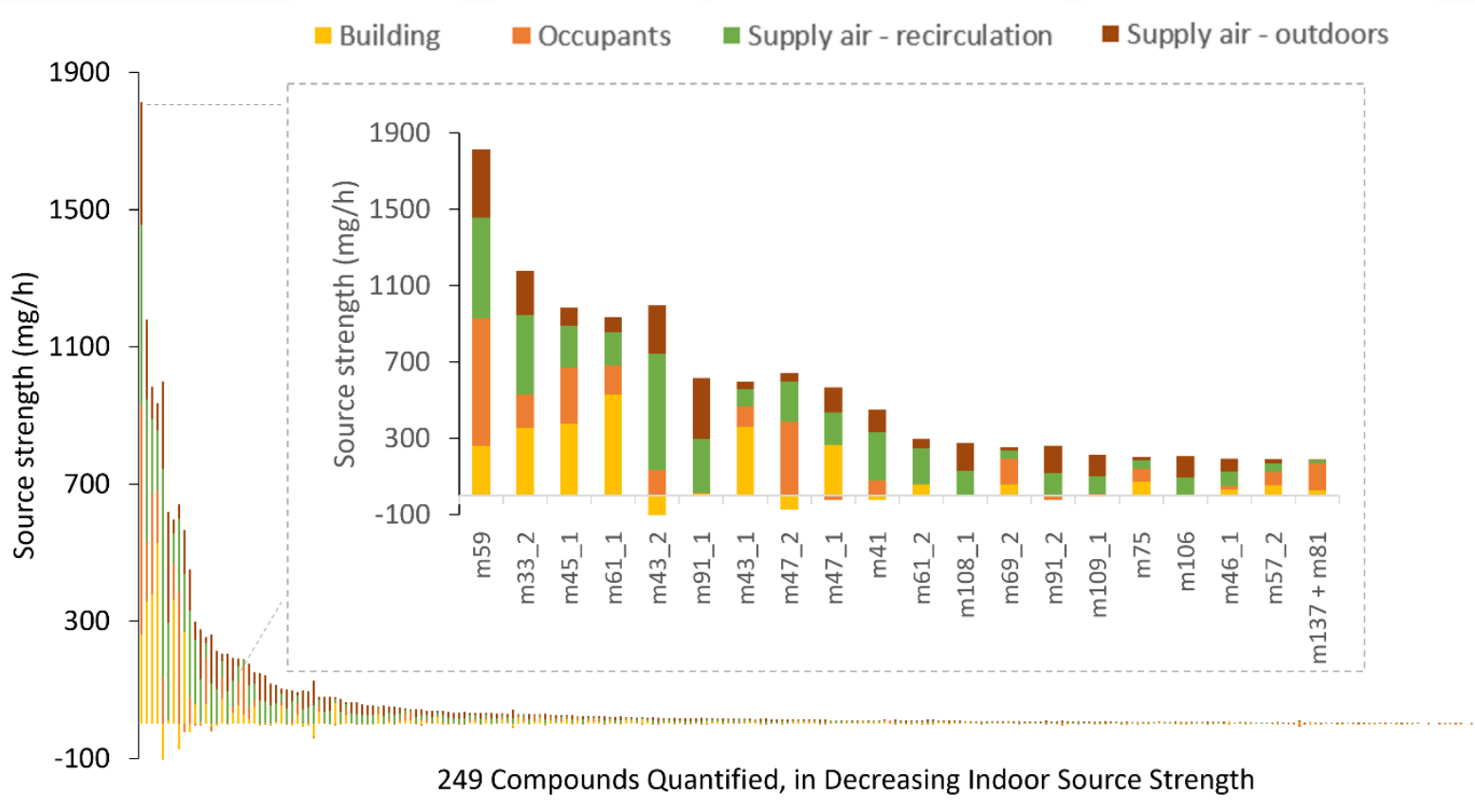

263 Figure 2. Source apportionment for 249 VOCs, with the 20 compounds with the highest source 264 strengths shown in the inset. Putatively identified compounds include acetone (m59), methanol 265 (m33_2), acetaldehyde (m45_1), acetic acid (m61_1), ethanol (m47_2), formic acid (m47_1), 266 isopropanol (m61_2), isoprene (m69_2), formamide (m46_1), and monoterpenes (m137+ m81).

267 Of the twenty largest indoor source strengths, nine are putatively identified; the

268 compound identification process is detailed in the Supporting Information and shown in Table 
269 S1. Acetone (m59) - a byproduct of human metabolism ${ }^{43}$ that is also found in building materials

270 and vehicle exhaust ${ }^{44}$ — has the highest total source strength; the majority ( $\left.51 \%\right)$ of its presence

271 was due to occupants and recirculated air. Methanol (m33_2) and ethanol (47_2) have the second

272 and eighth highest source strengths, respectively, both alcohols that include human exhaled

273 breath as a source. ${ }^{45}$ The majority of ethanol's presence is due to occupants and recirculation air,

274 while the primary source of methanol is the building itself and recirculated air, likely due to

275 methanol's inclusion in industrial solvents and adhesives. Acetaldehyde (m45_1), the compound

276 with the third highest source strength, is formed in the body due to the breakdown of ethanol ${ }^{46}$

277 and is also present in building materials such as linoleum and laminate. ${ }^{47}$ Its source strength is

278 distributed close to evenly between occupants and the building. Isoprene (m69_2), a byproduct

279 of human metabolism, ${ }^{48}$ and monoterpenes $(\mathrm{m} 137+\mathrm{m} 81)$, a family of compounds present in

280 personal care and cleaning products, ${ }^{49,50}$ are apportioned primarily to occupants. Note that

281 custodial cleaning activities occurred after the end of the school day and are not included in

282 source strength estimates made here. Acetic acid (m61_1) and formic acid (m47_1) are present

283 primarily due to building emissions, ${ }^{51}$ while isopropanol (m61_2) is present most prominently in

284 recirculation air, implying persistence across the carbon scrubber. In fact, we observe a highly

285 variable net emission of isopropanol across the air handler (see Table S3), perhaps due to its

286 presence in solvents used in the supply air fans or desorption/emission from the carbon scrubber.

287 For a detailed tabulation of quantified source apportionment across all 249 compounds, see

288 Table S3.

289 Indoor ozone mixing ratios during the campaign are consistently near-zero $(<2 \mathrm{ppb}$, the

290 uncertainty of the instrument) while outdoor ozone levels range $<2-48 \mathrm{ppb} .{ }^{37}$ A major

291 contributor to low indoor ozone mixing ratios is removal to the activated carbon scrubber in the 
292 air handler; this is shown in a prior study. ${ }^{52}$ While we assume that reactions with ozone are not a

293 major contributor to VOC loss in this study, even low levels of ozone may contribute to

294 transformation of indoor organic compounds. If occurring, transformation and sorptive processes

295 are accounted for in our estimates of emission rates since our measurements of VOCs and ozone

296 are made in the return air of the building.

297 For example, several compounds (including m47_2, putatively identified as ethanol)

298 show a negative $S_{\text {Building; }}$; a recent study shows ethanol partitions readily into a variety of indoor

299 surfaces. ${ }^{8}$ In the case of ozone chemistry, a recent study shows low levels of ozone result in

300 measurable emissions of 6-MHO, ranging $0.05-0.4 \mathrm{ppb} / \mathrm{h} .{ }^{53}$ There exist two possible peaks

301 where 6-MHO may be observed in our mass spectra: ${ }^{17}$ the parent compound, with protonated

302 mass 127.1123 and a dehydrated form at protonated mass 109.101177. As shown in Table S3,

303 we have closer agreement in our mass identification with the dehydrated form (m/z 109_3),

304 though we note this analysis is speculative as we did not calibrate for 6-MHO. At this signal,

$305 S_{\text {occupants }}$ and $S_{\text {building }}$ total $12 \pm 1.8 \mathrm{mg} / \mathrm{h}$, or $0.06 \mathrm{ppb} / \mathrm{h}$. When considering the high occupancy of

306 the school, the low potential emission of 6-MHO is in general alignment with the expected very

307 low-ozone environment. Interestingly, on Monday of our study, the building was unoccupied for

$308 \sim 50$ hours and we observe $S_{\text {building }}$ of $4 \pm 0.6 \mathrm{mg} / \mathrm{h}$, or $0.02 \mathrm{ppb} / \mathrm{h}$. This value is $\sim 50 \%$ lower than

309 that observed in Liu et al. ${ }^{53}$ after $50 \mathrm{~h}$ of no occupancy; we speculate that this is again indicative

310 of low indoor ozone, but still indicates a potential modest contribution of indoor ozone chemistry

311 to reported VOC source strengths in this study.

312 Fig. 3 presents a visualization of four compounds of particular interest at the near-

313 roadway school. As expected, for VOCs typically associated with human activity such as

314 monoterpenes and isoprene, occupant contributions account for the highest percentage of 
315 apportionment. In contrast, for benzene - found in vehicle exhaust — supply air accounts for the

316 highest percentage of apportionment. This suggests that benzene is entering the school after

317 being pushed through the air-cleaning system, albeit at reduced concentrations than would be

318 present absent the activated carbon scrubber. As for xylenes/ethylbenzene, the building itself

319 accounts for the highest percentage of apportionment. We speculate that this result is due to the

320 relatively low concentrations of outdoor xylenes/ethylbenzene during the study period (averaging

$3210.2 \mu \mathrm{g} / \mathrm{m}^{3}$ across daytime periods over the three occupied days) and that these compounds are

322 present in solvents, a variety of consumer products, ${ }^{54}$ and building materials. ${ }^{55}$
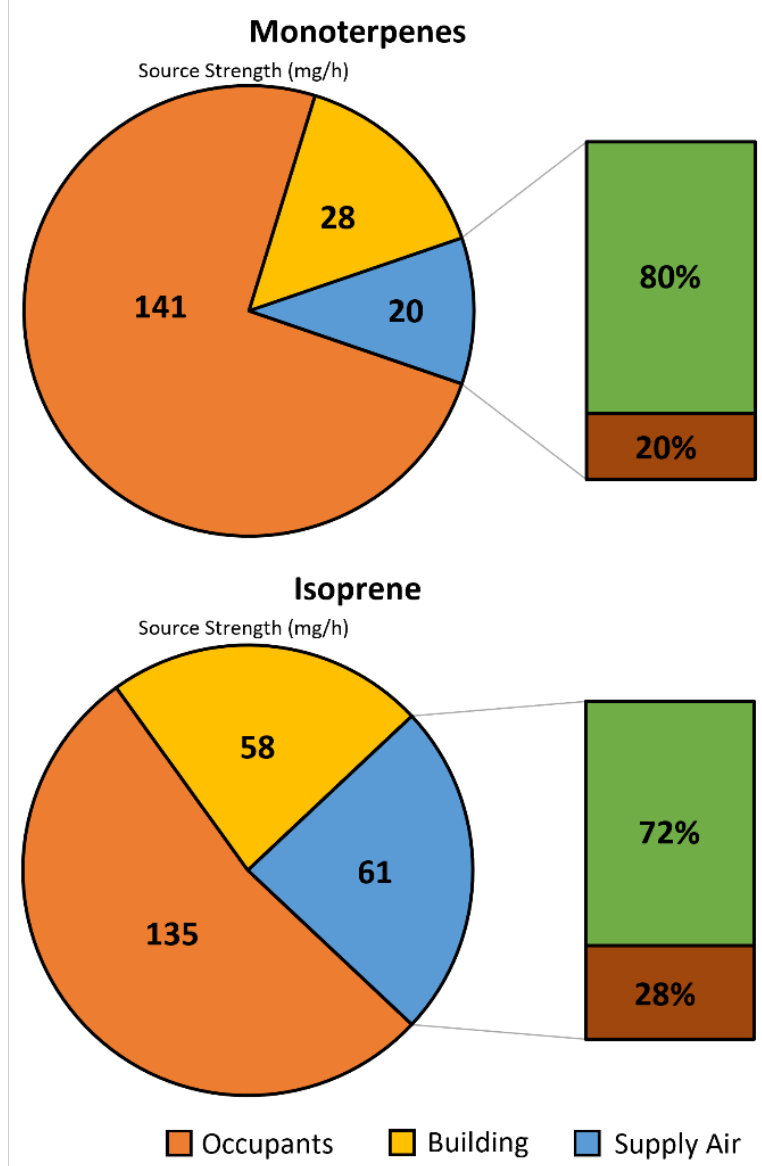

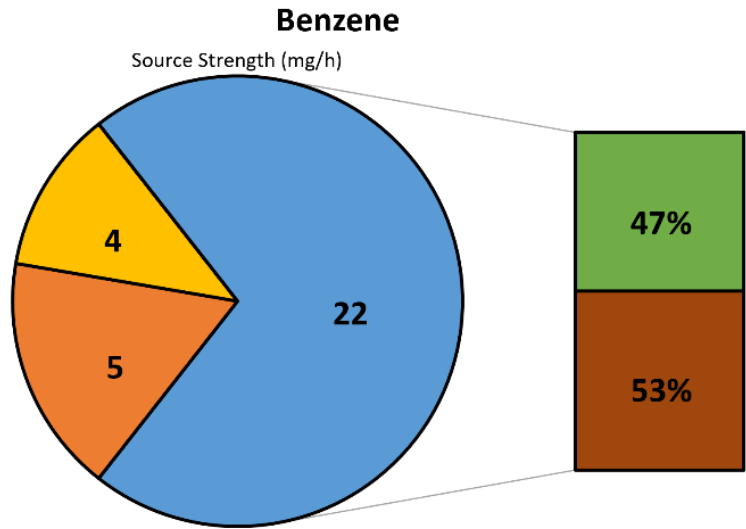

Xylenes + Ethylbenzene

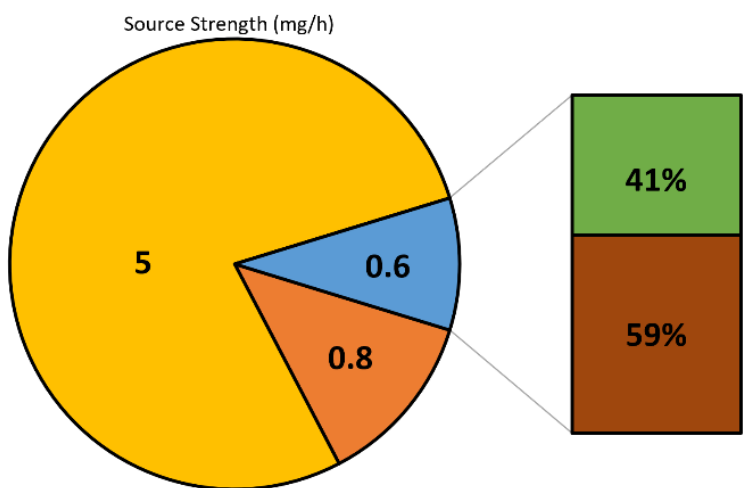

Supply Air (Recirculation)

Supply Air (Outdoor)

Figure 3. Apportionment of source strength $(\mathrm{mg} / \mathrm{h})$ for four select compounds of interest: monoterpenes and isoprene, which are associated with human activity, as well as benzene and xylenes/ethylbenzene, which are associated with vehicle exhaust.

\subsection{Whole-building emissions and area emission factors}


Using the data presented in Fig. 2 and an estimate of the building footprint $\left(5800 \mathrm{~m}^{2}\right.$,

330 determined via Google Earth, see Fig. S4), approximations of whole-building emission flux can

331 be made. Note that VOC measurements made in the return air (AHU-1, see Fig. 1) of the air

332 handler are representative of exhaust air, as a portion of return air is immediately exhausted

333 through a louvered "penthouse" above AHU-1. While the building was intended to remain nearly

334 balanced in return and supply airflow rate, infiltration and exfiltration are likely occurring

335 through the building envelope. Spatially resolved VOC measurements and estimates of

336 infiltration rates and mechanical ventilation rates would enable further exploration on the impact

337 of infiltration on whole-building emission rates. Further, chemical reactions can occur on

338 building envelope surfaces ${ }^{57,58}$ and envelope materials may directly emit VOCs. ${ }^{59}$ On the whole,

339 we speculate these processes cause our estimates to be slightly lower than the true whole-

340 building emission rate.

341 The total whole-building VOC source strength in building air exhausted to the outdoors

342 via the air handler is calculated from eq. 8; summing over all quantified VOCs in this study, we

343 calculate $S_{\text {exhaust }}$ of $8.5 \pm 0.4 \mathrm{~g} / \mathrm{h}$. Note that this source strength includes the contribution of

344 outdoor air moving through the building to provide ventilation. The VOC source strength in

345 building exhaust air determined here by summing the relevant building sources and sinks (i.e.,

346 eq. 9) yields a whole-building VOC source strength of $8.6 \pm 1.8 \mathrm{~g} / \mathrm{h}$. These two estimates of

347 whole-building VOC source strength are within propagated uncertainty, indicating reasonable

348 mass closure is achieved.

349 The unoccupied building $\left(S_{\text {Building }}\right)$ and occupants and their activities $\left(S_{\text {Occupants }}\right)$ are

350 sources of VOCs to the outdoor environment that are generated indoors; these two sources sum

351 to $5.9 \pm 1.7 \mathrm{~g} / \mathrm{h}$, a substantial contribution to the whole-building VOC emission rate in exhaust air. 
352 On an area-normalized basis, the unoccupied building and the occupants and their activities emit 353 a total of $1020 \pm 300 \mu \mathrm{g} \mathrm{m}^{-2} \mathrm{~h}^{-1}$. This area emission factor from indoor sources is consistent with 354 recent estimates of urban oxygenated VOC fluxes of $1000-3000 \mu \mathrm{g} \mathrm{m}^{-2} \mathrm{~h}^{-1}$, and approximately $35520-50 \%$ of the non-methane VOC emission flux estimated for an urban area in the same study. ${ }^{60}$

356 The building area emission factor of each VOC analyzed in this work is reported in Table S3

357 with putative identification available in Table S1. This study provides evidence that occupied 358 buildings may represent a substantial fraction of the urban non-methane VOC emission

359 inventory. Note that in this study, only one siloxane is quantified (hexamethylcyclotrisiloxane,

360 D3). In Section 4.4 we use prior reported estimates of per-person emissions of D4-D6 siloxanes

361 to estimate that these three compounds may contribute an additional $\sim 1.4 \mathrm{~g} / \mathrm{h}$ to the indoor 362 source strength quantified here.

363 Two compounds of specific interest include isoprene and monoterpenes, reactive VOCs

364 important in indoor and outdoor air chemistry. Normalizing the contributions from $S_{\text {Building }}$ and

365 Soccupants, whole-building area emission factors were $29 \pm 5.7 \mu \mathrm{g} \mathrm{m}^{-2} \mathrm{~h}^{-1}$ for monoterpenes and

$36633 \pm 5.1 \mu \mathrm{g} \mathrm{m}^{-2} \mathrm{~h}^{-1}$ for isoprene. For comparison, plants are important monoterpene sources, 367 emitting in the range of $\sim 10-500 \mu \mathrm{g} \mathrm{m}^{-2} \mathrm{~h}^{-1}$ across the United States, with the higher limit 368 representative of dense forest in the southeast United States. ${ }^{61}$ The isoprene emission flux from 369 this middle school is $\sim 10 \%$ of the rate measured in a major metropolitan area ${ }^{62}$ and the isoprene 370 and monoterpene area emission factors determined here are within the range reported for urban 371 land-use in the United Kingdom. ${ }^{63}$ Notably, these prior estimates of monoterpene and isoprene 372 area emission factors includes biogenic sources, like urban tree canopy. The isoprene and 373 monoterpene area emission factors determined for HTMS are of non-plant origin. This implies 374 occupied buildings are an important source of reactive organic compounds to the outdoor 
375 environment. Since buildings comprise $>20 \%$ of the footprint of an urban environment, ${ }^{64}$

376 estimation of emission fluxes from buildings may be needed to improve accuracy of urban and

377 regional VOC emission inventories.

$378 \quad 4.4$ Per-person emission factors

379 Four studies quantifying per-person VOC emission factors served as a reference for this

380 work, including a study in a university classroom, ${ }^{17}$ a cinema, ${ }^{18}$ an art museum ${ }^{19}$, and a residential

381 test house. ${ }^{65}$ In contrast, our study of a middle school includes $\sim 505$ individuals, approximately

$38290 \%$ of them children between the ages of 11 and $16 .{ }^{40}$ A list of per-person emission factors for

383 the 249 VOCs quantified here is shown in Table S3.

Per-person emission factors are, in general, consistent with prior studies, though we observe higher values for isoprene, monoterpenes, ethanol, methanol, and acetaldehyde. For example, isoprene emissions $\left(270 \pm 60 \mu \mathrm{g}\right.$ person ${ }^{-1} \mathrm{~h}^{-1}$ here $v s .60-162 \mu \mathrm{g}$ person $^{-1} \mathrm{~h}^{-1}$ across three

387 studies ${ }^{17-19,65}$ ) may be higher due to eating and physical exercise activities that occur inside the 388 school; there exists an indoor gymnasium and cafeteria in the building volume served by the air 389 handling system. Monoterpene emissions $\left(280 \pm 80 \mu\right.$ person $^{-1} \mathrm{~h}^{-1}$ here $v$ s. $25-300 \mu \mathrm{g}$ person $^{-1} \mathrm{~h}^{-1}$ 390 across three studies ${ }^{17-19,65}$ ) are in close agreement with the "high personal care product use"

391 noted by Arata et al., ${ }^{65}$ consistent with expectations of usage of scented personal care products in 392 the studied middle-school population. Ethanol emissions vary substantially in this study

$393\left(770 \pm 3200 \mu \mathrm{g}\right.$ person $\left.{ }^{-1} \mathrm{~h}^{-1}\right)$, in-line with prior estimates. ${ }^{17-19,65}$ We suspect this high variability is 394 due to ethanol in cleaning, sanitizing, and personal care products that are used throughout the 395 building in unknown frequency and quantity. Cooking is also a known source of ethanol and 396 other VOCs; ${ }^{65}$ cooking activity each day likely also contributes to the observed variability in 397 ethanol emissions. Methanol emissions are less variable than ethanol $\left(350 \pm 250 \mu \mathrm{g} \mathrm{person}^{-1} \mathrm{~h}^{-1}\right)$ 
398 and are in agreement with an estimate made in the afternoon by Arata et al. ${ }^{65}$ Acetaldehyde

399 emissions measured here $\left(590 \pm 250 \mu \mathrm{g}_{\text {person }}{ }^{-1} \mathrm{~h}^{-1}\right)$ are higher than those measured previously,

400 ranging $114-242 \mu \mathrm{g}$ person ${ }^{-1} \mathrm{~h}^{-1}$ across three studies. ${ }^{17-19}$

401 Siloxanes are an important class of compounds with environmental concerns that are

402 emitted in large quantities into indoor environments due to personal care product use. ${ }^{66,67}$ Our

403 campaign was originally designed to study select traffic-related air pollutants, and so our

404 analytical window extends from 17-280 amu. This means we can estimate only the source

405 strength of hexamethylcyclotrisiloxane (D3), tentatively identified at mass m_223 (see Table S1

406 for exact mass). At this signal, we estimate a per person emission factor of $5.3 \pm 6.7 \mu \mathrm{g} \mathrm{person}^{-1} \mathrm{~h}^{-}$

$407{ }^{1}$, which is similar to the median D3 emission reported by Tang et al. ${ }^{17}\left(3.3 \mu \mathrm{g}\right.$ person $\left.{ }^{-1} \mathrm{~h}^{-1}\right)$. The

408 sum of D4-D6 siloxanes reported by Tang et al. ${ }^{17}$ gives a median per-person emission rate of

$4092800 \mu \mathrm{g}$ person $^{-1} \mathrm{~h}^{-1}$. At the average occupancy of $\sim 500$ in the school studied here, this equates

410 to $1.4 \mathrm{~g} / \mathrm{h}$ of potentially unquantified indoor VOC emissions. If added to the $5.9 \mathrm{~g} / \mathrm{h}$ of quantified

411 VOC emissions in this study, the estimated D4-D6 contribution to the source strength of the

412 school is $\sim 20 \%$. This is in close agreement with Tang et al. ${ }^{17}$ showing D4-D6 contribute $\sim 27 \%$ of

413 total indoor VOC source strength.

$414 \quad 4.5$ Removal efficiency of VOCs in an air handler with activated carbon scrubber

415 Shown in Fig. 4 and Fig S5 of the supporting information are the calculated removal

416 efficiency of the 249 studied compounds, categorized by net removal, net source, or no effect.

417 The categorization is based on evaluation of propagated uncertainty relative to $0 \%$ removal. If

418 the lower bound of uncertainty is $>0 \%$, we categorize net removal; if the upper bound of

419 uncertainty is $<0 \%$, net source; if the uncertainty includes $0 \%$, no effect. 
421 removes a net $2.4 \pm 0.4 \mathrm{~g} / \mathrm{h}$ of VOCs. This is a substantial reduction in indoor VOC source

422 strength; for steady-state conditions with an outdoor air exchange rate of $1 \mathrm{~h}^{-1}$ (see Table 1), the

423 carbon scrubber results in a $65 \mu \mathrm{g} / \mathrm{m}^{3}$ decrease in indoor organic compound concentration. In

424 Fig. S6 of the supporting information, we evaluate whether the challenge concentration upstream

425 the scrubber or compound protonated molecular weight can explain variance in observed

426 removal efficiency; there is no easily discernible relationship between these two variables and

427 the determined removal efficiency.

428

429

430

431

432

433

434

435

436 437

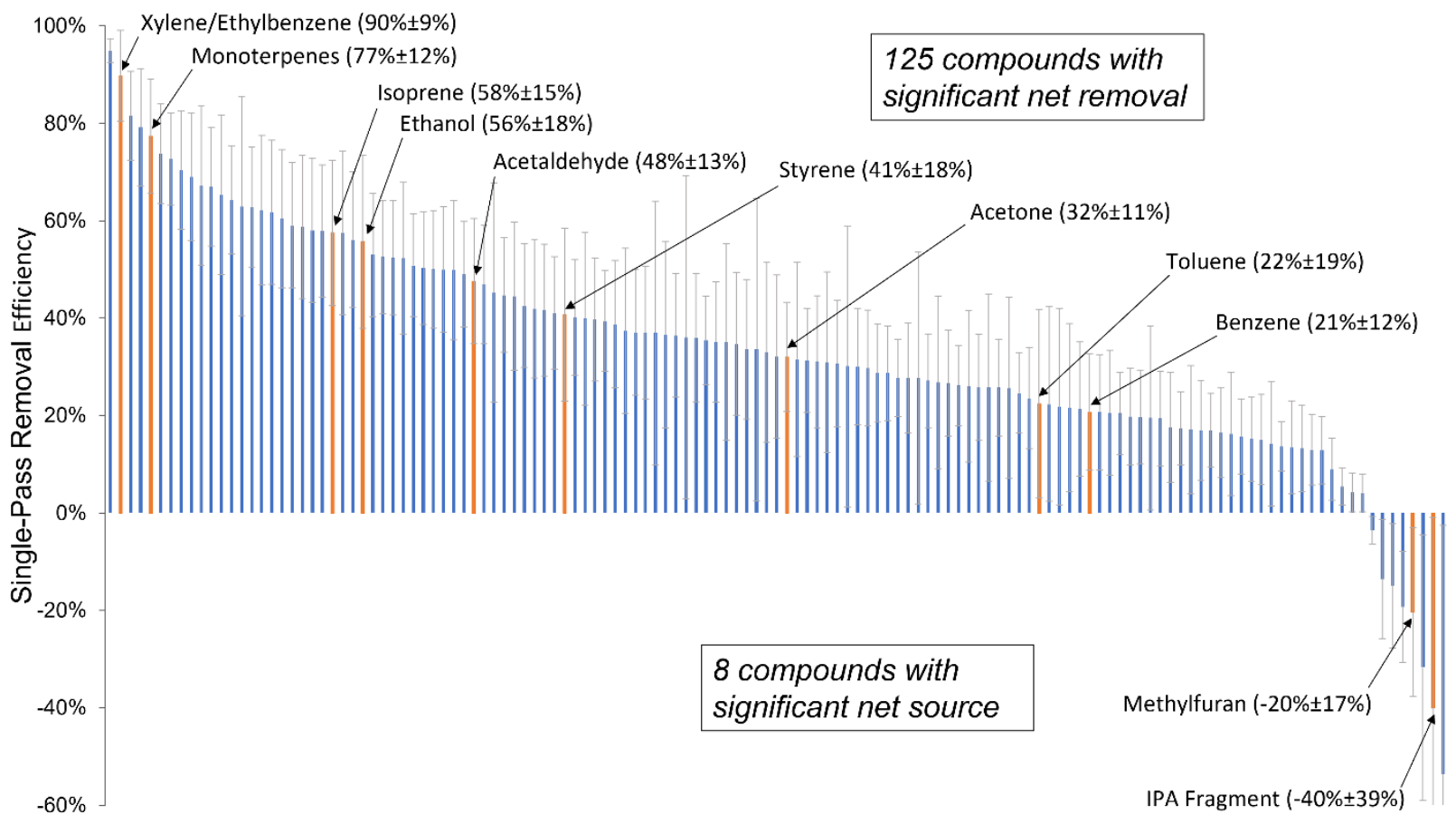

Figure 4. Single-pass removal efficiencies across the carbon scrubber for the 125 compounds with significant net removal and 8 compounds with significant net source. Note that there were 116 compounds with no significant observed effect - see the supporting information in Figure S5 for a plot of removal efficiencies and uncertainty associated with these compounds. Note that for clarity in the above figure, the vertical axis extends to $-60 \%$ and the lower-bound of uncertainty on the two right-most compounds are not shown; the uncertainty bounds are symmetric around the indicated estimate of removal. Reported removal efficiencies and uncertainties for all measured compounds can be found in Table S3 of the Supporting Information. 
Monoterpenes and isoprene are removed relatively effectively across the scrubber, at

$43977 \pm 11 \%$ and $58 \pm 15 \%$, respectively. Since monoterpenes and isoprene are important compounds

440 in indoor chemistry, ${ }^{68}$ this result implies carbon scrubbing may "quench" chemistry that

441 produces harmful secondary products, like secondary organic aerosol. Select alcohols, aldehydes,

442 and ketones associated with human activity are removed with lower efficiency, such as ethanol

443 (56 $\pm 18 \%)$, acetaldehyde (48 $\pm 13 \%)$, acetone $(32 \pm 11 \%)$ and methanol $(21 \pm 14 \%)$. For BTEX

444 compounds, xylenes/ethylbenzene have high removal efficiency of $90 \pm 9 \%$, while toluene and

445 benzene are lower, at $22 \pm 19 \%$ and $21 \pm 12 \%$ respectively. We suspect that the lower measured

446 removal efficiencies are indicative of a source of toluene and benzene in the air handler

447 downstream the scrubber, rather than such a large range in removal across BTEX compounds.

448 Laguerre et al. ${ }^{37}$ found that during the same sampling campaign approximately one month prior

449 to this study period, the removal efficiencies of xylenes/ethylbenzene, toluene, and benzene

450 across the carbon scrubber were $89 \%, 91 \%$, and $93 \%$, respectively. In that campaign, BTEX

451 compounds were measured directly upstream and downstream the carbon scrubber using sorbent

452 cartridges analyzed off-line with GC/MS, possible due to the battery powered sampling pumps

453 that could be placed directly in the air handler. Access for PTR-ToF-MS sampling lines were

454 limited to locations identified in Fig. 1.

455 The fate of volatile organic compounds emitted indoors may include indoor chemical 456 transformation, ${ }^{69}$ partitioning to indoor surfaces, ${ }^{8}$ or emission to the outdoors via exhaust in the

457 air handler or exfiltration. As discussed in Section 4.3, we estimate a net whole-building area

458 emission factor due to the building and occupants of $5.9 \pm 1.7 \mathrm{~g} / \mathrm{h}$. Since the carbon scrubber

459 removes $2.4 \pm 0.4 \mathrm{~g} / \mathrm{h}$, the contribution of indoor processes to VOC emissions in building exhaust

460 (Sexhaust,indoor, eq. 10) is reduced from $\sim 5.9 \mathrm{~g} / \mathrm{h}$ to $\sim 3.5 \mathrm{~g} / \mathrm{h}, \mathrm{a} 40 \%$ reduction. Note this calculation 
461 credits the removal of a VOC of outdoor origin to the reduction of the whole-building emission

462 factor since the air cleaning system is part of the building.

463 While it is generally known that carbon scrubbing can reduce indoor VOC levels, it is

464 rarely employed in buildings. This is due, in part, to many important unknowns that remain

465 concerning cost, carbon breakthrough time, and system-level impacts (e.g., pressure drop and

466 resulting energy implications) that limit practical application. However, this study shows that

467 carbon scrubbing may also yield a meaningful reduction in VOCs emitted outdoors from a

468 building, a previously unrecognized benefit to gas-phase air cleaning in buildings. The potential

469 for both indoor and outdoor air quality improvement may compel further research needed to

470 resolve the challenges that limit widespread use of activated carbon air cleaning in buildings.

$471 \quad 4.6$ Study limitations

472 There existed a narrow window of opportunity to conduct this study; it was enabled by a

473 weekday holiday where the building was unoccupied and the air handler operated on its normal

474 weekday schedule. This single day for estimation of emissions from the unoccupied building is a

475 source of uncertainty. For this reason, we limited the analysis of occupied days to those close in

476 time (the same week) to the unoccupied day. Because we relied on injection of $\mathrm{CO}_{2}$ by metabolic

477 activity of occupants to determine air change rates, airflows could not be empirically determined

478 for the unoccupied day_instead, we assumed the average values of airflows over the three

479 occupied days applied to the unoccupied day. Estimates of air change are made in the afternoon

480 and assumed to apply during the period of VOC analysis earlier in the day. While we include

481 efforts to validate the reasonableness of our estimates, future studies should seek to directly

482 monitor airflows through the building to complement the high time resolution monitoring

483 enabled by on-line mass spectrometry. Finally, our analysis is predicated upon an assumption of 
484 mixing in the school building as air enters the building from supply air, pollutants emit into the 485 school, and air is then returned to the air handler. It is possible that the spatial distribution of 486 emissions throughout the school introduced uncertainty into our estimate of source strengths.

487 However, our sampling location within the air handler allowed for mixing among the various 488 return branches prior to return via a single duct that served the air handler where our

489 measurement occurred. Reasonable agreement between measured air change rates and 490 occupancy with design values and enrollment, as well as per-person estimates of metabolic

491 emissions generally consistent with what prior estimates are present in the literature, indicate 492 accuracy for the whole-building approach used here.

493 Author Contributions

494 BS contributed data curation, formal analysis, visualization, writing - original draft, and 495 writing - review \& editing; AL contributed data curation, formal analysis, investigation, 496 methodology, writing - original draft, and writing - review \& editing; ETG contributed 497 conceptualization, funding acquisition, investigation, methodology, project administration, 498 resources, supervision, validation, visualization, writing - original draft, and writing - review \& 499 editing.

\section{Acknowledgements}

501 We thank the Portland Public School district for funding the monitoring campaign at 502 Harriet Tubman Middle School under IGA\#65793. This material is based upon work supported 503 by the National Science Foundation under Grant No. 1356679. We thank the Portland State 504 University's McNair Scholars Program, Grant Number P217A170270, for their support.

\section{Supporting Information}


507 description of PTR-MS compound identification and quantification; a table describing putatively

508 assigned empirical formulas and exact masses; a description of the mass balance derivations that

509 enabled parameter estimations; a table showing parameter uncertainty estimates; a detailed table

510 of calculated source strengths, removal efficiencies, and associated uncertainties; regression of

511 calculated removal efficiencies vs. potential explanatory variables; and relevant tables and

512 figures in Tables S1-S3 and Figures S1-S6. 


\section{References}

(1) Klepeis, N. E.; Nelson, W. C.; Ott, W. R.; Robinson, J. P.; Tsang, A. M.; Switzer, P.; Behar, J. V.; Hern, S. C.; Engelmann, W. H. The National Human Activity Pattern Survey (NHAPS): A Resource for Assessing Exposure to Environmental Pollutants. J. Expo. Anal. Environ. $\quad$ Epidemiol. $\quad$ 2001, $11 \quad$ 231-252. http://dx.doi.org.proxy.lib.pdx.edu/10.1038/sj.jea.7500165.

(2) Weisel, C. P.; Alimokhtari, S.; Sanders, P. F. Indoor Air VOC Concentrations in Suburban and Rural New Jersey. Environ. Sci. Technol. 2008, 42 (22), 8231-8238. https://doi.org/10.1021/es8005223.

(3) Goodman, N. B.; Wheeler, A. J.; Paevere, P. J.; Selleck, P. W.; Cheng, M.; Steinemann, A. Indoor Volatile Organic Compounds at an Australian University. Build. Environ. 2018, 135, 344-351. https://doi.org/10.1016/j.buildenv.2018.02.035.

(4) Lunderberg, D. M.; Misztal, P. K.; Liu, Y.; Arata, C.; Tian, Y.; Kristensen, K.; Weber, R. J.; Nazaroff, W. W.; Goldstein, A. H. High-Resolution Exposure Assessment for Volatile Organic Compounds in Two California Residences. Environ. Sci. Technol. 2021, 55 (10), 6740-6751. https://doi.org/10.1021/acs.est.0c08304.

(5) Wang, T. C. A Study of Bioeffluents in a College Classroom. ASHRAE Trans. 1975, 81 (1), 32-44.

(6) Zhang, X.; Wargocki, P.; Lian, Z. Physiological Responses during Exposure to Carbon Dioxide and Bioeffluents at Levels Typically Occurring Indoors. Indoor Air 2016. https://doi.org/10.1111/ina.12286.

(7) Zhang, X.; Wargocki, P.; Lian, Z.; Xie, J.; Liu, J. Responses to Human Bioeffluents at Levels Recommended by Ventilation Standards. Procedia Eng. 2017, 205, 609-614. https://doi.org/10.1016/j.proeng.2017.10.415.

(8) Wang, C.; Collins, D. B.; Arata, C.; Goldstein, A. H.; Mattila, J. M.; Farmer, D. K.; Ampollini, L.; DeCarlo, P. F.; Novoselac, A.; Vance, M. E.; Nazaroff, W. W.; Abbatt, J. P. D. Surface Reservoirs Dominate Dynamic Gas-Surface Partitioning of Many Indoor Air Constituents. Sci. Adv. 2020, 6 (8), eaay8973. https://doi.org/10.1126/sciadv.aay8973.

(9) Weschler, C. J. Chemistry in Indoor Environments: 20 Years of Research. Indoor Air 2011, 21 (3), 205-218. https://doi.org/10.1111/j.1600-0668.2011.00713.x.

(10) Weschler, C. J. New Directions: Ozone-Initiated Reaction Products Indoors May Be More Harmful than Ozone Itself. Atmos. Environ. 2004, 38 (33), 5715-5716. https://doi.org/10.1016/j.atmosenv.2004.08.001.

(11) Andersson, K.; Bakke, J. V.; Bjørseth, O.; Bornehag, C.-G.; Clausen, G.; Hongslo, J. K.; Kjellman, M.; Kjærgaard, S.; Levy, F.; Mølhave, L.; Skerfving, S.; Sundell, J. TVOC and Health in Non-Industrial Indoor Environments. Indoor Air 1997, 7 (2), 78-91. https://doi.org/10.1111/j.1600-0668.1997.t01-2-00002.x.

(12) Logue, J. M.; McKone, T. E.; Sherman, M. H.; Singer, B. C. Hazard Assessment of Chemical Air Contaminants Measured in Residences. Indoor Air 2011, 21 (2), 92-109. https://doi.org/10.1111/j.1600-0668.2010.00683.x.

(13) Logue, J. M.; Price, P. N.; Sherman, M. H.; Singer, B. C. A Method to Estimate the Chronic Health Impact of Air Pollutants in U.S. Residences. Environ. Health Perspect. 2012, 120 (2), 216-222. https://doi.org/10.1289/ehp.1104035.

(14) Bentayeb, M.; Billionnet, C.; Baiz, N.; Derbez, M.; Kirchner, S.; Annesi-Maesano, I. Higher Prevalence of Breathlessness in Elderly Exposed to Indoor Aldehydes and VOCs in a 
Representative Sample of French Dwellings. Respir. Med. 2013, 107 (10), 1598-1607. https://doi.org/10.1016/j.rmed.2013.07.015.

(15) Logue, J. M.; Mckone, T. E.; Sherman, M. H.; Singer, B. C. Hazard Assessment of Chemical Air Contaminants Measured in Residences. Indoor Air 2011. https://doi.org/10.1111/j.1600-0668.2010.00683.x.

(16) Allen, J. G.; MacNaughton, P.; Satish, U.; Santanam, S.; Vallarino, J.; Spengler, J. D. Associations of Cognitive Function Scores with Carbon Dioxide, Ventilation, and Volatile Organic Compound Exposures in Office Workers: A Controlled Exposure Study of Green and Conventional Office Environments. Environ. Health Perspect. 2016. https://doi.org/10.1289/ehp.1510037.

(17) Tang, X.; Misztal, P. K.; Nazaroff, W. W.; Goldstein, A. H. Volatile Organic Compound Emissions from Humans Indoors. Environ. Sci. Technol. 2016, 50 (23), 12686-12694. https://doi.org/10.1021/acs.est.6b04415.

(18) Stönner, C.; Edtbauer, A.; Williams, J. Real-World Volatile Organic Compound Emission Rates from Seated Adults and Children for Use in Indoor Air Studies. Indoor Air 2018. https://doi.org/10.1111/ina.12405.

(19) Pagonis, D.; Price, D. J.; Algrim, L. B.; Day, D. A.; Handschy, A. V.; Stark, H.; Miller, S. L.; De Gouw, J.; Jimenez, J. L.; Ziemann, P. J. Time-Resolved Measurements of Indoor Chemical Emissions, Deposition, and Reactions in a University Art Museum. Environ. Sci. Technol. 2019. https://doi.org/10.1021/acs.est.9b00276.

(20) Gall, E. T.; Mishra, A. K.; Li, J.; Schiavon, S.; Laguerre, A. Impact of Cognitive Tasks on CO2 and Isoprene Emissions from Humans. Environ. Sci. Technol. 2021, 55 (1), 139-148. https://doi.org/10.1021/acs.est.0c03850.

(21) Warneke, C.; Gkatzelis, G.; McDonald, B. C.; Peischl, J.; Aikin, K. C.; Gilman, J.; Trainer, M.; Coggon, M. M. Volatile Chemical Products Have a Major Impact on Air Quality in U.S. Cities. 2020, 2020, A184-0017.

(22) McDonald, B. C.; Gouw, J. A. de; Gilman, J. B.; Jathar, S. H.; Akherati, A.; Cappa, C. D.; Jimenez, J. L.; Lee-Taylor, J.; Hayes, P. L.; McKeen, S. A.; Cui, Y. Y.; Kim, S.-W.; Gentner, D. R.; Isaacman-VanWertz, G.; Goldstein, A. H.; Harley, R. A.; Frost, G. J.; Roberts, J. M.; Ryerson, T. B.; Trainer, M. Volatile Chemical Products Emerging as Largest Petrochemical Source of Urban Organic Emissions. Science 2018, 359 (6377), 760-764. https://doi.org/10.1126/science.aaq0524.

(23) Coggon, M. M.; Gkatzelis, G. I.; McDonald, B. C.; Gilman, J. B.; Schwantes, R. H.; Abuhassan, N.; Aikin, K. C.; Arend, M. F.; Berkoff, T. A.; Brown, S. S.; Campos, T. L.; Dickerson, R. R.; Gronoff, G.; Hurley, J. F.; Isaacman-VanWertz, G.; Koss, A. R.; Li, M.; McKeen, S. A.; Moshary, F.; Peischl, J.; Pospisilova, V.; Ren, X.; Wilson, A.; Wu, Y.; Trainer, M.; Warneke, C. Volatile Chemical Product Emissions Enhance Ozone and Modulate Urban Chemistry. Proc. Natl. Acad. Sci. 2021, 118 (32). https://doi.org/10.1073/pnas.2026653118.

(24) Qin, M.; Murphy, B. N.; Isaacs, K. K.; McDonald, B. C.; Lu, Q.; McKeen, S. A.; Koval, L.; Robinson, A. L.; Efstathiou, C.; Allen, C.; Pye, H. O. T. Criteria Pollutant Impacts of Volatile Chemical Products Informed by Near-Field Modelling. Nat. Sustain. 2021, 4 (2), 129-137. https://doi.org/10.1038/s41893-020-00614-1.

(25) Shah, R. U.; Coggon, M. M.; Gkatzelis, G. I.; McDonald, B. C.; Tasoglou, A.; Huber, H.; Gilman, J.; Warneke, C.; Robinson, A. L.; Presto, A. A. Urban Oxidation Flow Reactor Measurements Reveal Significant Secondary Organic Aerosol Contributions from Volatile 
Emissions of Emerging Importance. Environ. Sci. Technol. 2020, 54 (2), 714-725. https://doi.org/10.1021/acs.est.9b06531.

(26) MacNeill, M.; Dobbin, N.; St-Jean, M.; Wallace, L.; Marro, L.; Shin, T.; You, H.; Kulka, R.; Allen, R. W.; Wheeler, A. J. Can Changing the Timing of Outdoor Air Intake Reduce Indoor Concentrations of Traffic-Related Pollutants in Schools? Indoor Air 2016, 26 (5), 687-701. https://doi.org/10.1111/ina.12252.

(27) Gall, E. T.; George, L. A. IEQ Applications: Reducing Exposures: Traffic-Related Air Pollution and Urban Building Design. ASHRAE J. 2018, 60 (9), 80-83.

(28) HEI. Traffic-Related Air Pollution: A Critical Review of the Literature on Emissions, Exposure, and Health Effects. Spec. Rep. Institute's Panel Health Eff. Traffic-Relat. Air Pollut. Health Eff. Inst. 2010.

(29) Kingsley, S. L.; Eliot, M. N.; Carlson, L.; Finn, J.; Macintosh, D. L.; Suh, H. H.; Wellenius, G. A. Proximity of US Schools to Major Roadways: A Nationwide Assessment. J. Expo. Sci. Environ. Epidemiol. 2014. https://doi.org/10.1038/jes.2014.5.

(30) Karner, A. A.; Eisinger, D. S.; Niemeier, D. A. Near-Roadway Air Quality: Synthesizing the Findings from Real-World Data. Environ. Sci. Technol. 2010, 44 (14), 5334-5344. https://doi.org/10.1021/es100008x.

(31) Hu, S.; Fruin, S.; Kozawa, K.; Mara, S.; Paulson, S. E.; Winer, A. M. A Wide Area of Air Pollutant Impact Downwind of a Freeway during Pre-Sunrise Hours. Atmos. Environ. 2009, 43 (16), 2541-2549. https://doi.org/10.1016/j.atmosenv.2009.02.033.

(32) Rivas, I.; Querol, X.; Wright, J.; Sunyer, J. How to Protect School Children from the Neurodevelopmental Harms of Air Pollution by Interventions in the School Environment in the Urban Context. Environ. Int. 2018. https://doi.org/10.1016/j.envint.2018.08.063.

(33) McCarthy, M. C.; Ludwig, J. F.; Brown, S. G.; Vaughn, D. L.; Roberts, P. T. Filtration Effectiveness of HVAC Systems at Near-Roadway Schools. Indoor Air 2013, 23 (3), 196207. https://doi.org/10.1111/ina.12015.

(34) Polidori, A.; Fine, P. M.; White, V.; Kwon, P. S. Pilot Study of High-Performance Air Filtration for Classroom Applications. Indoor Air 2013, 23 (3), 185-195. https://doi.org/10.1111/ina.12013.

(35) Scheepers, P. T. J.; Hartog, J. J. de; Reijnaerts, J.; Beckmann, G.; Anzion, R.; Poels, K.; Godderis, L. Influence of Combined Dust Reducing Carpet and Compact Air Filtration Unit on the Indoor Air Quality of a Classroom. Environ. Sci. Process. Impacts 2015, 17 (2), 316325. https://doi.org/10.1039/C4EM00506F.

(36) Gall, E. T. Indoor and Outdoor Air Quality at Harriet Tubman Middle School and the Design of Mitigation Measures: Phase I Report; 2018.

(37) Laguerre, A.; George, L. A.; Gall, E. T. High-Efficiency Air Cleaning Reduces Indoor Traffic-Related Air Pollution and Alters Indoor Air Chemistry in a Near-Roadway School. Environ. Sci. Technol. 2020, $54 \quad$ (19), 11798-11808. https://doi.org/10.1021/acs.est.0c02792.

(38) de Gennaro, G.; Dambruoso, P. R.; Loiotile, A. D.; Di Gilio, A.; Giungato, P.; Tutino, M.; Marzocca, A.; Mazzone, A.; Palmisani, J.; Porcelli, F. Indoor Air Quality in Schools. Environ. Chem. Lett. 2014, 12 (4), 467-482. https://doi.org/10.1007/s10311-014-0470-6.

(39) Annesi-Maesano, I.; Baiz, N.; Banerjee, S.; Rudnai, P.; Rive, S.; the SINPHONIE Group. Indoor Air Quality and Sources in Schools and Related Health Effects. J. Toxicol. Environ. Health Part B 2013, 16 (8), 491-550. https://doi.org/10.1080/10937404.2013.853609. 
(40) Oregon Department of Education: Adapted At-A-Glance School and District Profiles for the 2019-20 School Year: At-A-Glance School and District Profiles: State of Oregon https://www.oregon.gov/ode/schools-and-districts/reportcards/reportcards/Pages/AdaptedAt-A-Glance-1920.aspx (accessed 2021 -09-07).

(41) Lindinger, W.; Hansel, A.; Jordan, A. Proton-Transfer-Reaction Mass Spectrometry (PTRMS): On-Line Monitoring of Volatile Organic Compounds at Pptv Levels. Chem. Soc. Rev. 1998, 27 (5), 347-354. https://doi.org/10.1039/a827347z.

(42) Rim, D.; Gall, E. T.; Kim, J. B.; Bae, G.-N. Particulate Matter in Urban Nursery Schools: A Case Study of Seoul, Korea during Winter Months. Build. Environ. 2017, 119, 1-10. https://doi.org/10.1016/j.buildenv.2017.04.002.

(43) Barker, M.; Hengst, M.; Schmid, J.; Buers, H.-J.; Mittermaier, B.; Klemp, D.; Koppmann, R. Volatile Organic Compounds in the Exhaled Breath of Young Patients with Cystic Fibrosis. Eur. Respir. J. 2006, 27 (5), 929-936. https://doi.org/10.1183/09031936.06.00085105.

(44) Rogers, T. M.; Grimsrud, E. P.; Herndon, S. C.; Jayne, J. T.; Kolb, C. E.; Allwine, E.; Westberg, H.; Lamb, B. K.; Zavala, M.; Molina, L. T.; Molina, M. J.; Knighton, W. B. OnRoad Measurements of Volatile Organic Compounds in the Mexico City Metropolitan Area Using Proton Transfer Reaction Mass Spectrometry. Int. J. Mass Spectrom. 2006, 252 (1), 26-37. https://doi.org/10.1016/j.ijms.2006.01.027.

(45) Fenske, J. D.; Paulson, S. E. Human Breath Emissions of VOCs. J. Air Waste Manag. Assoc. 1999. https://doi.org/10.1080/10473289.1999.10463831.

(46) Kurkivuori, J.; Salaspuro, V.; Kaihovaara, P.; Kari, K.; Rautemaa, R.; Grönroos, L.; Meurman, J. H.; Salaspuro, M. Acetaldehyde Production from Ethanol by Oral Streptococci. Oral Oncol. 2007, 43 (2), 181-186. https://doi.org/10.1016/j.oraloncology.2006.02.005.

(47) Giberti, A.; Carotta, M. C.; Fabbri, B.; Gherardi, S.; Guidi, V.; Malagù, C. High-Sensitivity Detection of Acetaldehyde. Sens. Actuators B Chem. 2012, 174, 402-405. https://doi.org/10.1016/j.snb.2012.08.016.

(48) Watson, W. P.; Cottrell, L.; Zhang, D.; Golding, B. T. Metabolism and Molecular Toxicology of Isoprene. Chem. Biol. Interact. 2001, 135-136, 223-238. https://doi.org/10.1016/S0009-2797(01)00192-2.

(49) Yeoman, A. M.; Shaw, M.; Carslaw, N.; Murrells, T.; Passant, N.; Lewis, A. C. Simplified Speciation and Atmospheric Volatile Organic Compound Emission Rates from NonAerosol Personal Care Products. Indoor Air 2020, 30 (3), 459-472. https://doi.org/10.1111/ina.12652.

(50) Michelle Wang, C.; Barratt, B.; Carslaw, N.; Doutsi, A.; E. Dunmore, R.; W. Ward, M.; C. Lewis, A. Unexpectedly High Concentrations of Monoterpenes in a Study of UK Homes. Environ. Sci. Process. Impacts 2017, $19 \quad$ (4), 528-537. https://doi.org/10.1039/C6EM00569A.

(51) Smedemark, S. H.; Ryhl-Svendsen, M.; Schieweck, A. Quantification of Formic Acid and Acetic Acid Emissions from Heritage Collections under Indoor Room Conditions. Part I: Laboratory and Field Measurements. Herit. Sci. 2020, 8 (1), 58. https://doi.org/10.1186/s40494-020-00404-0.

(52) Shields, H. C.; Weschler, C.; Naik, D. Ozone Removal by Charcoal Filters after Continuous Extensive Use (5 to 8 Years). In Indoor Air 99, the 8th International Conference on Indoor Air Quality and Climate; Edinburgh, Scotland, 1999; Vol. 4, pp 4-0049. 
(53) Liu, Y.; Misztal, P. K.; Arata, C.; Weschler, C. J.; Nazaroff, W. W.; Goldstein, A. H. Observing Ozone Chemistry in an Occupied Residence. Proc. Natl. Acad. Sci. 2021, 118 (6). https://doi.org/10.1073/pnas.2018140118.

(54) Lim, S. K.; Shin, H. S.; Yoon, K. S.; Kwack, S. J.; Um, Y. M.; Hyeon, J. H.; Kwak, H. M.; Kim, J. Y.; Kim, T. H.; Kim, Y. J.; Roh, T. H.; Lim, D. S.; Shin, M. K.; Choi, S. M.; Kim, H. S.; Lee, B.-M. Risk Assessment of Volatile Organic Compounds Benzene, Toluene, Ethylbenzene, and Xylene (BTEX) in Consumer Products. J. Toxicol. Environ. Health A 2014, 77 (22-24), 1502-1521. https://doi.org/10.1080/15287394.2014.955905.

(55) Lucialli, P.; Marinello, S.; Pollini, E.; Scaringi, M.; Sajani, S. Z.; Marchesi, S.; Cori, L. Indoor and Outdoor Concentrations of Benzene, Toluene, Ethylbenzene and Xylene in Some Italian Schools Evaluation of Areas with Different Air Pollution. Atmospheric Pollut. Res. 2020, 11 (11), 1998-2010. https://doi.org/10.1016/j.apr.2020.08.007.

(56) Weisel, C. P.; Zhang, J.; Turpin, B. J.; Morandi, M. T.; Colome, S.; Stock, T. H.; Spektor, D. M.; Korn, L.; Winer, A. M.; Kwon, J.; Meng, Q. Y.; Zhang, L.; Harrington, R.; Liu, W.; Reff, A.; Lee, J. H.; Alimokhtari, S.; Mohan, K.; Shendell, D.; Jones, J.; Farrar, L.; Maberti, S.; Fan, T. Relationships of Indoor, Outdoor, and Personal Air (RIOPA). Part I. Collection Methods and Descriptive Analyses. Res. Rep. Health Eff. Inst. 2005, No. 130 Pt 1, 1-107; discussion 109-127.

(57) Stephens, B.; Gall, E. T.; Siegel, J. A. Measuring the Penetration of Ambient Ozone into Residential Buildings. Environ. Sci. Technol. 2012, 46 (2), 929-936. https://doi.org/10.1021/es2028795.

(58) Zhao, H.; Gall, E. T.; Stephens, B. Measuring the Building Envelope Penetration Factor for Ambient Nitrogen Oxides. Environ. Sci. Technol. 2019, 53 (16), 9695-9704. https://doi.org/10.1021/acs.est.9b02920.

(59) Chin, K.; Laguerre, A.; Ramasubramanian, P.; Pleshakov, D.; Stephens, B.; Gall, E. T. Emerging Investigator Series: Primary Emissions, Ozone Reactivity, and Byproduct Emissions from Building Insulation Materials. Environ. Sci. Process. Impacts 2019, 21 (8), 1255-1267. https://doi.org/10.1039/C9EM00024K.

(60) Karl, T.; Striednig, M.; Graus, M.; Hammerle, A.; Wohlfahrt, G. Urban Flux Measurements Reveal a Large Pool of Oxygenated Volatile Organic Compound Emissions. Proc. Natl. Acad. Sci. 2018, 115 (6), 1186-1191. https://doi.org/10.1073/pnas.1714715115.

(61) Sakulyanontvittaya, T.; Duhl, T.; Wiedinmyer, C.; Helmig, D.; Matsunaga, S.; Potosnak, M.; Milford, J.; Guenther, A. Monoterpene and Sesquiterpene Emission Estimates for the United States. Environ. Sci. Technol. 2008, 42 (5), 1623-1629. https://doi.org/10.1021/es702274e.

(62) Park, C.; Schade, G. W.; Boedeker, I. Characteristics of the Flux of Isoprene and Its Oxidation Products in an Urban Area. J. Geophys. Res. Atmospheres 2011, 116 (D21). https://doi.org/10.1029/2011JD015856.

(63) Owen, S. M.; MacKenzie, A. R.; Stewart, H.; Donovan, R.; Hewitt, C. N. Biogenic Volatile Organic Compound (Voc) Emission Estimates from an Urban Tree Canopy. Ecol. Appl. 2003, 13 (4), 927-938. https://doi.org/10.1890/01-5177.

(64) Akbari, H.; Shea Rose, L.; Taha, H. Analyzing the Land Cover of an Urban Environment Using High-Resolution Orthophotos. Landsc. Urban Plan. 2003, 63 (1), 1-14. https://doi.org/10.1016/S0169-2046(02)00165-2.

(65) Arata, C.; Misztal, P. K.; Tian, Y.; Lunderberg, D. M.; Kristensen, K.; Novoselac, A.; Vance, M. E.; Farmer, D. K.; Nazaroff, W. W.; Goldstein, A. H. Volatile Organic 
Compound Emissions during HOMEChem. Indoor Air n/a (n/a). https://doi.org/10.1111/ina.12906.

(66) Tang, X.; Misztal, P. K.; Nazaroff, W. W.; Goldstein, A. H. Siloxanes Are the Most Abundant Volatile Organic Compound Emitted from Engineering Students in a Classroom. Environ. Sci. Technol. Lett. 2015, 2 (11), 303-307. https://doi.org/10.1021/acs.estlett.5b00256.

(67) Salthammer, T. Emerging Indoor Pollutants. Int. J. Hyg. Environ. Health 2020, 224, 113423. https://doi.org/10.1016/j.ijheh.2019.113423.

(68) Youssefi, S.; Waring, M. S. Transient Secondary Organic Aerosol Formation from Limonene Ozonolysis in Indoor Environments: Impacts of Air Exchange Rates and Initial Concentration Ratios. Environ. Sci. Technol. 2014, 48 (14), 7899-7908. https://doi.org/10.1021/es5009906.

(69) Waring, M. S.; Wells, J. R. Volatile Organic Compound Conversion by Ozone, Hydroxyl Radicals, and Nitrate Radicals in Residential Indoor Air: Magnitudes and Impacts of Oxidant Sources. Atmos. Environ. 2015, 106, 382-391. https://doi.org/10.1016/j.atmosenv.2014.06.062. 